\title{
HISTORICAL AND DYNAMIC REVIEW OF POLISH AND AZERBAIJANI RELATIONS (FROM CULTURAL RELATIONS TO ECONOMIC RELATIONS)
}

\author{
Toghrul Allahmanli \\ Lodz University, Poland \\ DOI: https://doi.org/10.31435/rsglobal_ijite/30122019/6849
}

\section{ARTICLE INFO}

Received 20 October 2019

Accepted 13 December 2019

Published 30 December 2019

\section{KEYWORDS}

Economic relations, Historical relations, Export, Import. ABSTRACT

Cultural ties are primarily based on economic relations between Poland and Azerbaijan. These links, which date back to the fifteenth century, have always been in the ascending direction. The visits of Azerbaijani intellectuals to Poland in the 19th century, as well as the interest of Polish Orientalists to Azerbaijani literature and culture are indicative of this. The great epic "Koroglu", created by the Azerbaijani people, was first published by Polish Orientalists and published as a book. In addition, at the beginning of the 20th century, the most magnificent architectural monuments in Baku were created by Polish architects. After Russia's occupation of Azerbaijan, a significant number of prominent intellectuals fled to Poland. The policy pursued by Azerbaijan in the cultural, economic and political spheres since the 1990s is a new milestone in the history of both Poland and Azerbaijan. All of this makes it clear that historical links are on the rise.
\end{abstract}

Citation: Toghrul Allahmanli. (2019) Historical and Dynamic Review of Polish and Azerbaijani Relations (from Cultural Relations to Economic Relations). International Journal of Innovative Technologies in Economy. 7(27). doi: 10.31435/rsglobal_ijite/30122019/6849

Copyright: (C) 2019 Toghrul Allahmanli This is an open-access article distributed under the terms of the Creative Commons Attribution License (CC BY). The use, distribution or reproduction in other forums is permitted, provided the original author(s) or licensor are credited and that the original publication in this journal is cited, in accordance with accepted academic practice. No use, distribution or reproduction is permitted which does not comply with these terms.

Introduction. An analysis of relations between Azerbaijan and Poland at the same level needs to clarify the history of political and cultural relations. Because, at the beginning of all things, cultural ties are at stake and everything starts from there. The information provided by historical sources, scientific literature, and print media is indicative of a wealth of facts. Since the beginning of the XIX century Poland's interest in science, culture, creative environment, geography and the Caucasus, as well as its part in Azerbaijan, has always been on the rise. Architectural monuments, Polish ethnographers, archaeologists, historians, literary critics and musicians make this clear. For example, Polish orientalist Josef Sepkovski's translations, Romanovic's articles on Baku and its architecture (1825), as well as the construction of today's protected buildings as a magnificent architectural monument, are related to the names of Polish experts. The first edition of the Koroglu epic as a book, the first acquisition of ashug music (1842 by Alexander Hodzko) and others. It is an indication of these links, their interest in Azerbaijan. The Polish School of Oriental Studies has done a great deal of work in relation to Azerbaijan. The history of the PolishAzerbaijani cultural, political and economic relations dates back to the 15th century, when the state of Aggoyunlu. Poland had a special place in the political and cultural relations that Uzun Hassan had as president. The great work of the famous Azerbaijani diplomat Sara's letter in the fifteenth century continued through the following period. There are interesting points about Poland in the works of Ismail bey Kutgashinly and Abbasgulu aga Bakikhanov in the 19th century. The first information on the Azerbaijani folklore was given by Polish orientalist I. Chopin (1840). The notes of ashug music were also first introduced by Polish musician in the 1840s. It is no coincidence that Azerbaijan prefers cultural ties with Poland after independence in the early 20th century. After Azerbaijan was invaded by Bolshevik Russia in 1920, most of the intellectuals preferred to go to Poland. For example, the head of the Republic of 
Azerbaijan MA Rasulzade (his wife is Polish) went to Poland and lived there for a while. Prominent military officer Vali bey Sadigbey oglu Yadigarov went to Poland (1921) after the invasion of the republic (his wife was Polish). He was the commander of the cavalry and the commander of the 10th cavalry division in the Army Kraiova in Poland. There is a memorial in Poland. The course of events during the Soviet era is another one. Since Azerbaijan's independence, these relations have always been in the state direction. Therefore, the general picture of these two countries following the collapse of the Soviet Union, the study of the level of development, is characterized by the essential features and the richness of the facts.

Problem setting. The Republic of Azerbaijan and the Polish Republic, with their history and traditions of statehood, are connected to the ancient and medieval times. Thus, according to historical sources, the first Polish state dates back to the 10th century (966) and coincides with the borders of today's Polish Republic. This state, which became a kingdom in 1025, united with the Lithuanian dynasty in 1569, laid the foundations of the Polish-Lithuanian union and collapsed in 1795. Poland regained its independence in 1918 and was again occupied by the Second World War. After the defeat of the Germans, it was under the control of the Soviet Union and gained independence again following the collapse of the regime (1989). This structure is emphasized by modern historiography as the "third republic" in Polish history. Poland is a member of the European Union, NATO, UN, Economic Cooperation Organization, World Trade Organization. It ranks sixth in the European Union in terms of population. Poland, a liberal democratic country of sixteen regions, is of particular importance as a partner with all economic indicators and capabilities.

As for the Republic of Azerbaijan, there are quite basic studies related to its history, rich cultural fund of the people, and traditions of statehood. It is both the oldest living place in the world and one of the oldest cultural centers in the world. Azikh cave, Gurchay culture, Dripli characterized by serious archeological facts. Archaeologists from different countries have been paying more attention to Azerbaijan in recent years. Ethnographers, historians, musicologists, etc. his interests and monographs are an example of this. The history of statehood has been measured for thousands of years. All these are justified by the fact that the economic parallels at the level of Azerbaijan and the Polish Republic are being monitored and the processes taking place in the economy of recent times. As you can see, the industry structure, historical perspectives and features of the economy of Azerbaijan and Poland enable rich analysis and are characterized by an invoice in the context of the processes taking place in the European and Asian economies. With its vast territory and population in Europe, Poland is of great importance for Azerbaijan as a serious economic partner.

Both Poland and Azerbaijan have made significant progress in liberalizing society and the economy. The concept of systematic approach implemented by the country in this direction has been the basis for success in various fields. For the success of economic processes, the scientific literature emphasizes the following trends: liberalization, stabilization, privatization, economic institutions, restructuring of the economy for any country. In essence, the essence of these lines lies in the solution of the fundamental problems that Azerbaijan and Poland are making and taking necessary steps in this area. Already, economic institutions, in almost all areas of the economy, perform systematic analyzes, and can make meaningful conclusions by analyzing what is happening in the country and the world economy. Over the past decades of independence, the general patterns of economic restructuring have been studied, and global challenges of modernization have been identified and the necessary successes in that direction have been achieved. The specifics, tendencies and prospects of the Azerbaijani economy have been clarified. The same is true when considering the development dynamics of the Polish economy. Therefore, the comparative study of the development of the Azerbaijani and Polish economy, the structure of the industry, and the comparative study of foreign economic relations is characterized by greater accuracy.

There are similarities here as both of them lived the same weight under the Soviet Union and had a close thinking system. The mechanisms underlying their ideological systems were also the basis for their economic picture. They have established political, ideological, cultural behavior within the same circle as a single system. The situation they are facing after the collapse of the Soviet Union reveals the same picture. That is why serious ties and intimacy between these countries arise, and it is the basis for economic cooperation in the context of mutual understanding. The agreements, treaties, promising projects, documents signed between Azerbaijan and Poland at the level of international economic relations are the result of this successful start, mutually beneficial relations. The processes that take place in the modern economic picture of the world, the formation of geo-economic space, and the new content, in essence, undoubtedly make it necessary to participate in and follow these processes. 
Poland recognized the independence of Azerbaijan on December 27, 1991, and on February 21, 1992 diplomatic relations were established between the two countries. The Polish Embassy in Poland was established in 2001, and in 2004 the Embassy of Azerbaijan in Poland. Significant progress in the Azerbaijan-Poland economic and trade relations has been made in recent years. Oil and oil products dominate in the products exported from Azerbaijan. There are great prospects for cooperation in the energy sector as well. This indicates that Azerbaijan's importance in ensuring Poland's energy security will increase in the coming years.

Taking into account statistical data of recent times, it is clear that the Polish industry is characterized by high rates and is of interest to the diversity. Mechanical engineering, chemical industry, agrarian industry, metallurgy, forestry and others increase in the field is an example of this. In addition, furniture production, construction materials and construction have a special weight. Light and heavy industry, chemical industry, shipbuilding, metal industry, aircraft, machinery, cement, aluminum are the main industrial aspects. Recently, the wood and paper industries, textile and forest products also play a special role in the economic life of the country. The mining and mining industries are well developed. The most important of these are coal, zinc and copper. Efficiency of underground resources also proves that Poland is a serious partner in international economic relations. All these are the basis for the success of foreign economic relations and geo-economic relations between Poland and Azerbaijan. As it is known, the geo-economic space of Europe differs by its economic performance and the weight of its economic potential. Therefore, in terms of power and potential, these countries themselves are governed by different economic relations. For example, countries in the eurozone have more favorable advantages. The positive in the EU countries is that economic stability is being observed as a special case. This is what the European Commission has highlighted. The Czech Republic, Sweden, Romania and Poland are among the highest economic growth rates. Let us add that Poland is the sixth largest European country in terms of potential economic opportunities. This, in turn, explains the importance of Poland's economic opportunities and the overall picture of development.

For clarity, let's take a look at some of the goods produced in Poland; These include electronics, helicopters and aircraft (PZL Swidnik, PZL Mielec), ships (Gdansk Shipyard, Szczecin Shipyard, Gdynia Poland Marine Corps), bus and tram (Solaris, Solbus), military equipment (FB "Lucznik" Radedy, Labum-SA) ), chemical products, medicines (Polpharma, Polfa), glass pottery (Boleslawiec), food (Tymbark, Hortex, E.Wedel), clothing (LLP). In addition, Poland is one of the largest copper, silver and coal producers in the world. All this creates serious opportunities for the establishment of mutual economic relations in the geo-economic sphere.

Poland, European Union, NATO, UN, World Trade Organization, Economic Cooperation and Development Organization (OECD), European Economic Area, Operations in Europe, International Atomic Energy Agency, European Space Agency, G6, Baltic States Council, Visegrad Group, Weimar It is represented in international organizations and groups such as the Schengen Understanding. In some of these, Azerbaijan and Poland are united under the same system and participate in the implementation of various problems and economic projects. That is, the world is shrinking significantly in the face of political, economic, and technological processes, as well as serious links for the development of relations and mutual understanding. The closure of Poland with the Baltic States and Azerbaijan's Caspian basin also facilitates the establishment of contacts and contact lines with other state bodies. As it is known, the Black Sea countries and the Caspian basin countries are the most important areas for the success of their geographical conditions, trade and transport. From ancient times, these areas, connecting the West and the East, the South and the North, have significant economic, political and cultural links as caravan routes. The collapse of the Soviet empire was a wakeup call to that, a basis for transnational projects. Big economic projects, the construction of oil and gas pipelines, the efforts of the world's power centers to represent them in these projects all show that the processes on the global economic map are more global than separations, and that global interests are important. It is fully understood as the alphabet of the world economic sphere.

Bilateral cooperation of Poland and the Republic of Azerbaijan is based on mutual understanding, strengthening of economic ties, mutual benefit in the implementation of market relations and large projects. The arrival of high-level Polish government officials to Azerbaijan, as well as visits by the Azerbaijani government officials to Poland will further deepen economic relations and provide additional opportunities for joint activities. The Odessa-Brody Pipeline, an important part of the Eurasia Oil Corridor Project (EACTR), is implemented in the Sarmatia Consortium, which 
provides additional opportunities and benefits. Energy companies from Poland, Lithuania, Ukraine, Georgia and Azerbaijan are making significant success here. At the fourth meeting of the Polish and Azerbaijan Intergovernmental Commission (November 24, 2010), the Polish Prime Minister and the Minister of Economy emphasized the need to increase efficiency and the need to adapt Sarmatia to new conditions. Delivery of Azerbaijani oil to Ukraine and transportation of raw materials to Belarus was one of the key issues for establishing and successful development of foreign economic relations. The state and the modern landscape of these countries promise promising solutions to the existing problems, to meet the needs of the country, and to improve the living conditions of people. Therefore, it is important to take advantage of the opportunities available to sustainability in the country as the first step. At the end of the eighteenth century at the beginning of the nineteenth century, prominent economist D.Ricardo emphasized that "sometimes the large profits provided by private traders in foreign trade are the basis for the rise of the general profit rate in the country. Effective cooling from other jobs, using new and profitable foreign trade will generally increase prices and thereby increase profits". An important part of Poland's eastern policy is economic relations with Azerbaijan.

The Caspian basin is represented by the countries with great potential. Rich hydrocarbon deposits, oil strategy, and the growing trend in the non-oil sector give us a solid basis for creating a dynamic development and sustainability system using their coefficients of economic success. The energy resources of Azerbaijan, Kazakhstan and Turkmenistan underpin the need for new markets and new economic relations in the face of strong competition and make the region a point where economic interests are concentrated. The economic policy pursued by Russia, the United States, the European Union, and Iran has the potential for Azerbaijan at the same time. In addition, all this wealth, along with geo-economic interests, also represents a struggle for geopolitical and geostrategic positions.

Polish economist Jean Toporowski says in his article "Polish Contribution of Economics" that "there is no such thing as a national school in the economy. The ideas of Polish professional economists are largely derivative, as do the economists of many countries of the world; that is, the manifestation and extension of those of the past in one way or another"2. After the establishment of diplomatic relations between the two countries (February 21, 1992), the establishment of the Polish Embassy in Azerbaijan (2001) and the Embassy of Azerbaijan in Poland (2004) became the basis for economic revival and implementation of major projects. Agriculture, tourism, air transport, transportation, participation of Polish companies in Azerbaijani industrial parks, etc. it is of greater significance as a fact of understanding. The first official visit of the President of the Republic of Azerbaijan H.Aliyev to Poland (26-28 August 1997) was considered to be the development of bilateral relations. Declaration of friendship and cooperation, avoidance of double taxation, avoidance of income and property tax evasion, cultural and scientific cooperation, mutual promotion and protection of investments, real estate, cooperation in tourism, etc. the issues are in the works. During the Polish President's visit to Azerbaijan (October 27-29, 1998) economic cooperation was also in the spotlight. For example, the Memorandum of Mutual Understanding between the State Oil Company of the Republic of Azerbaijan and the Oil and Gas Company of the Republic of Poland and other important economic decisions was considered for the future development of the countries.

Further visits of the Azerbaijani President to Poland (5 March 2005, 26 February 2008, 26-28 June 2017), as well as visits by the Polish President to Azerbaijan (March 30, 2007, June 2, 2009) or at the GUAM Summit (June 18, 2007 in Baku, July 1, 2008 in Batumi), etc. The meetings were designed to improve bilateral cooperation. Charter of the Advisory Committee of the Presidents of the Republic of Azerbaijan and the Republic of Poland; all of which are designed to strengthen economic ties in one direction. At the last meeting (June 26-28, 2009), the business forum in the format of the plenary session reaffirms the more important nature of the issues and the need for mutual benefit in the economic field. The Joint Declaration on the Roadmap for Partnership and Economic Cooperation between the Republic of Poland and the Republic of Poland on that visit, as well as the five paragraphs, are the most obvious examples of strengthening economic ties between the two countries. For example, at a meeting with Polish President Andrzej Duda (June 26-28, 2017), the Polish President emphasized that "the economic potential of our countries is, in fact, very great and our trade

\footnotetext{
${ }^{1}$ Rikardo D. On the prinsiplen of political economy and taxation. Canada, Ontario, Kitchener, 2001, 85 p.

${ }^{2}$ Janek Toporowski. İqtisadiyyatda Polşa töhfəsi. www.res.org.uk/view/art4Apr14Features.html.
} 
exchanges are carried out. Its volume is about $\$ 100$ million a year." ${ }^{1}$ The views expressed by the Polish president in terms of economic cooperation in the Asian and European context are also of great importance. He said, "You have expressed your views on strengthening economic ties between Europe and Asia. I would like to note that our relations in transport should be expanded. We would like to see a direct railway line between Azerbaijan and Poland pass through Georgia and Ukraine. This is very important. Because of this, our transport corridor is, in fact, fully implemented by China's "One Pipeline, One Road" project. We are also part of this project and we provide access to India and Iran. We believe that we will expand our business relationships and contacts. We have great opportunities for Poland and Azerbaijan. For this reason, our economic relations are an important part of our bilateral relations. I am very pleased that our position on strengthening our economic cooperation with the Asian region coincides." Apparently, Azerbaijan as a country is not of interest to Poland at the level of Azerbaijan, of course it is an important player in economic relations, but on the other hand its strengthening relations with Asia is of great importance. China's "one-belt, one-way" principle is based on history, trade relations of nations that have been in the past.

Proper allocation of renewable and non-renewable resources in the overall context of Azerbaijan's foreign economic relations is important. It clarifies the purpose and purpose of the country's economic policy. Smith emphasized that "human progress seems unavoidable to have such a long-term sustainability by ensuring that any major country is effective for all three purposes. Even by all accounts, all over the world, the three richest countries (China, India, Egypt) are predominantly agricultural. They are not exclusive to foreign trade." 3 The economic picture of the world now requires analysis of all problems in a synchronous and diachronic manner with complex approaches. Because what is happening in the international arena and reality as a whole makes them an inevitable fact. The participation of Azerbaijan and Poland in economic policies and major projects, as well as the passage of both East-West and North-South corridors from Azerbaijan is the basis for the success of economic goals as a single territory. These issues were highlighted in the speech of the President of Azerbaijan (June 26-28, 2017, during the visit of the Azerbaijani President to Poland). He noted, "Both East-West and North-South transport corridors pass through Azerbaijan. All modern infrastructure has been created in our country. Seaports, railway airports, highways and regional cooperation format have also been established. Our task now is to deepen this cooperation and draw European countries to this cooperation. A recent meeting of railway executives in Baku suggests that a broader international cooperation format has already been established. The Polish side also participates in this format. This opens up great prospects for us. I am confident that coordination and joint efforts in this area will soon lead to good results, and all participating countries will benefit from this." ${ }^{4}$ The essence of Azerbaijan's economic cooperation with Poland lies in the mutual benefit, the economic advancement of problems, the successful implementation of the country's economic strategy, and the justification of the dynamics of these processes. Because both Azerbaijan and Poland are important in terms of economic cooperation and promise promising prospects. For example, the successful implementation of the Southern Gas Corridor project and the work in this area make exceptional promises in the European space. The first phase of this forty billion project is expected to be completed in 2018, and the second and final phase in 2020. This will open new perspectives in terms of sustainability and profitability of economic relations, and to clarify that Azerbaijan has a greater role as a partner for Europe. At the same time, it demonstrates in detail that Azerbaijan is a necessary partner in ensuring European energy security. The projects implemented within the framework of the regional cooperation format are aimed at strengthening the overall economic situation and improving the welfare of the people. Works in the field of transport, airports, seaports, railways, highways, etc. all are regulated by the principle of "one belt, one way." The essence of this is the principle of the correctness of economic processes in the home of the world, the desire to regulate joint economic relations of rights and states in a globalized world. This is the view given by those who have seen the main prospects of economic cooperation between Azerbaijan and Poland.

\footnotetext{
${ }^{1}$ Electronic resource: https://www.stat.gov.az/

${ }^{2}$ Electronic resource: https://www.stat.gov.az/

${ }^{3}$ Smith A. An inquiru into the nature and causes of the wealth of nations. USA, New York, Metalibri, 2007, $287 \mathrm{p}$

${ }^{4}$ Electronic resource: https://www.stat.gov.az/
} 
During the Polish Prime Minister's visit to Baku in May 2015, the Polish Ambassador to Azerbaijan Marek Tsalka specifically emphasized, "Despite the mutual sanctions of the countries, the Polish economy still maintains its economy and agriculture. Poland cooperates with many countries in Europe and Asia. In the first quarter of this year, Poland exported 5.4 billion euros. After the machinery and chemicals in the country, the food industry is ranked third in terms of exports." The main directions of economic relations of Azerbaijan and Poland are mechanical engineering, building materials and construction, chemical industry, metallurgy, agrarian industry, forestry and furniture production, light industry, heavy industry, shipbuilding, textile, automotive, aircraft, machinery, cement. , aluminum industry, etc. consists of. The wood and paper industries are also among them. This is the basis of foreign economic relations with Azerbaijan. When we look at Poland's economic growth trend, we see that the mining and mining industries are growing more and more. Poland, the largest coal producer in Europe (third place), has a successful trade relationship with Azerbaijan. All these are important areas of economic relations between Poland and Azerbaijan. In addition, according to analysts, about two-thirds of Poland's foreign trade are former communist bloc countries. These countries account for $35 \%$ of imports and $26 \%$ of exports. Import products include textile raw materials, iron ore, machinery and supplies, cereals and oil.

The agreements and treaties on economic cooperation of Azerbaijan with the Republic of Poland, and the agreements made by the large companies at the state and company levels are completely clear. The Joint Declaration on the Roadmap for Partnership and Economic Cooperation between the Republic of Poland and the Republic of Poland, accompanied by the visit of the President of the Republic of Azerbaijan to Poland (June 26-28, 2017), further signing of five documents is a necessary step towards further development of bilateral economic relations. As you can see, one of the noteworthy issues when pursuing the main directions of economic cooperation between Azerbaijan and Poland is that it creates a mechanism for the economic ties between the two countries, a full picture of the modern picture of internationalization.

Economic relations between Poland and Azerbaijan promise serious perspectives on each other in terms of geo-economic space. The directions highlighted in the official visit of the President of Azerbaijan to Poland, the organization of the business forum and discussions underline the importance of joint work not only at the state level, but also at the level of a separate company, private organization and sector. Agreement between the Oil and Gas Company of the Republic of Azerbaijan and the Oil and Gas Company of the Republic of Poland, etc. this is an obvious example. During his visit to the Republic of Poland (26-28 June 2017), the President of Azerbaijan emphasized that "Poland is developing rapidly. Poland has a very strong position in the international arena. Mutual relations, of course, cover the economic field. We have agreed that the current trade turnover cannot satisfy us. I hope that the business forum and its results will contribute to the development of our trade relations.

Transport and energy, I think, should be the focus of the economic bloc. In the energy sector, Azerbaijani oil is supplied to the Polish markets. Today, Azerbaijan successfully implements the Southern Gas Corridor Project, a major project with its partner countries. This project will transport Azerbaijani gas to Europe. The total cost of the project is $\$ 40$ billion, and the project is being continued successfully."2

In addition, the Baku-Tbilisi-Kars railway is the most successful in promoting Asian access to European and world markets. In the future, the transportation of goods to Europe and Asia will have a significant impact on the volume of foreign trade. At a meeting with the President of the Republic of Poland (June 26-28, 2017), the President of the Republic of Poland made a proposal to build an alternative road from Azerbaijan through Georgia and Ukraine, and said it would be good. As a geographical area, Azerbaijan plays an important role in establishing and developing economic relations with the Asian region. More precisely, transport communications opportunities in Azerbaijan are of great importance to all transnational countries, including Europe.

Conclusions. Thus, cultural relations are at the beginning of their relations with Azerbaijan and Poland. These relations have been the basis of economic and political ties between the two countries. Subsequent development and modern vision are also the basis for great success on this core. Therefore, the economic cooperation of these two countries promises great prospects and makes the

\footnotetext{
${ }^{1}$ Electronic resource: https://www.stat.gov.pl/

${ }^{2}$ Electronic resource: https://www.stat.gov.az/
} 
development of historical links more successful and positive. Light industry, heavy industry, metallurgy, agrarian industry, forestry (combine) and furniture production, shipbuilding, mechanical engineering, textile, automotive, aircraft, machinery, cement, aluminum, building materials and construction, chemical industry and others. From the point of view of the establishment of economic cooperation, it gives us reason to think of trade relations. As you know, Poland is a fairly advanced energy country. Powerful hydroelectric power stations, coal-based iron and steel industry are the country's most important sources of income. Large mechanical and electrical engineering operates with the industrial center, which plays an important role in the economic potential of the country. Azerbaijan is also an important Asian country in its economic cooperation with Poland, with its rich resources and advantages over its geographical location. All this clarifies the main directions and prospects of cultural and economic cooperation between Azerbaijan and Poland and the growing trend.

\section{REFERENCES}

1. Abbasov Ç. Azərbaycanın dünya iqtisadiyyatına inteqrasiya yolları. Bakı: Elm, 2005, $252 \mathrm{~s}$.

2. Oləkbərov Ә. Beynəlxalq iqtisadi münasibətlər. Bakı: Çaşığlu, 2010, $648 \mathrm{~s}$.

3. Janek Toporowski. İqtisadiyyatda Polşa töhfəsi. www.res.org.uk/view/art4Apr14Features.html.

4. Rikardo D. On the prinsiplen of political economy and taxation. Canada, Ontario, Kitchener, 2001, 333 p.

5. Simatupang Batara. The Polish Economic Crisis: Background, Causes, and Aftermath. London: Routledge, 1994, $272 \mathrm{p}$.

6. Smith A. An inquiru into the nature and causes of the wealth of nations. USA, New York, Metalibri, 2007, $754 \mathrm{p}$.

7. Stanislaw Starski. Class Struggle in Classless Poland. Boston: South End Press, 1982, 276 p.

8. Jankiewicz Sławomir. Uwarunkowania rozwoju polskiej gospodarki $\mathrm{w}$ dobie globalizacji $=$ The conditions for development of the polish economy in a world of globalization. Poland: Wydawnictwo Wyższej Szkoły Bankowej w Poznaniu, 2014, 126 p. 